\title{
Quranic Code of Tadabbur and its Methodologies
}

\author{
Shahzadi Pakeeza* \\ Humaira Jahangir*** \\ Hafsa Batool $^{* * * *}$
}

\begin{abstract}
The main objective of the Holy Quran is to build humans as a righteousness person. For this, understanding and focus on Quranic verses is a prerequisite. Therefore, Holy Quran gives the concept of tadabbur to inculcate the message of Allah Almighty with its real beauty. Without understanding the text and its particular meaning a person can't get the benefit from this book nor can he spend a successful life in this world and hereafter. Therefore, this paper deals with the ways and techniques to focus and concentrate on Holy Quran and proposes several ways to get maximum bounties and blessings from this divine book.
\end{abstract}

Keywords: thinking, understanding, divine book, rational, focus

\section{Introduction}

Tadabbur is derived from Arabic language word, Dabbara means to organize or making plan and Tadabbur means to think, consider and observe. Action of tadabbur is the continual struggle in reproducing the importance of the phrase. Some methods are required to understand verse deeply and to see whether the verse is described according to Allah's will or not. The method of tadabbur includes observation, investigation and research. Some definitions related to tadabbur are as follows:

\footnotetext{
${ }^{*}$ Dr. Shahzadi Pakeeza Assistant Professor, Department of Islamic Studies, Fatima Jinnah Women University, Rawalpindi. dr.pakeeza@fjwu.edu.pk

${ }^{* *}$ Ms. Humaira Jahangir Research Scholar, Department of Islamic Studies, Fatima Jinnah Women University, Rawalpindi

${ }^{* * *}$ Ms. Hafsa Batool Research Scholar, Department of Islamic Studies, Fatima Jinnah Women University, Rawalpindi
} 
1. Ibn Atiyyah says that tadabbur is to examine the reason behind interpretation.

2. Al Zamakhsyari says that to appreciate and to observe the meanings deeply.

3. Imam Ibn Khatir says that tadabbur means accepting the meanings or searching reasons behind the text of the Holy Quran.

\section{General Objectives of Tadabbur}

i. To study and explain concept and importance of tadabbur-ul-Quran the explanation should be related to the Holy Quran and Hadith.

ii. To rising the training of tadabbur and to define its impact.

\section{Specific Objectives of Tadabbur}

i. To define the importance of tadabbur.

ii. And to develop outline of tadabbur from the Holy Quran and Hadith. ${ }^{1}$

\section{Terminologies concerning Thinking as appeared in the Holy Quran}

Tadabbur comes in the Holy Quran in twenty one forms and forty four derivations for e.g. Yatadbbar (4 times) and plural form Yatadabbaren (2 times). For them who thinks and get knowledge from attaining the Holy Quran and thinking on its subjects, planning and information which get from stories. In the Holy Quran there is,

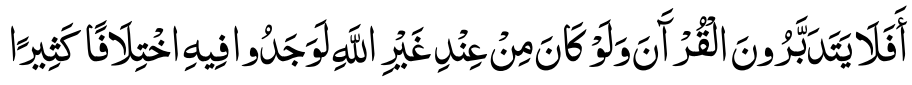

"Have you not pondered on the Quran were it be from person other than Allah it would have contain many contradiction."2

And at another place, it is mentioned:

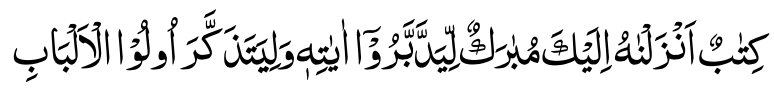

"The book revealed unto thee full of blessings so that they may ponder on its messages that shall be remembrance for the wise."3

\section{Concept of Tadabbur}

The concept of tadabbur is to examine something which is beyond its meaning. ${ }^{4}$ While someone is reading and listening to the Holy Quran, the feeling which a person gets from it is a target. Tadabbur needs research deeply and to get the 
meanings in common and to get expression in detail..$^{5}$ Imam Abu Hamid in his book lhya said that the process of making tadabbur is:

i. First absorb the meaning of text.

ii. Then express the feeling.

iii. And then do tadabbur with full appreciation. ${ }^{6}$

\section{The Signs of Tadabbur}

Some verses related to signs are as follows:

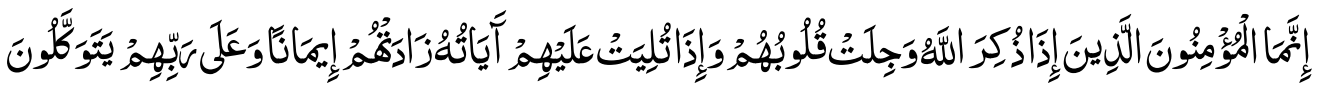

"The believers are only those who, when Allah is mentioned, feel a fear in their hearts and when His Verses (this Qur'an) are recited to them, they (i.e. the Verses) increase their Faith; and they put their trust in their Lord (Alone)."7

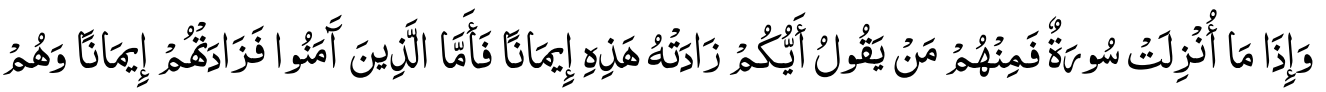

يَسْنَبْنُشُونَ

"And whenever there comes down a Surah (chapter from the Qur'an), some of them (hypocrites) say: "Which of you has had his Faith increased by it?" As for those who believe, it has increased their Faith, and they rejoice." 8

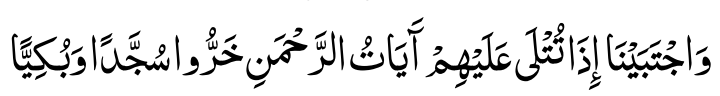

"When the Verses of the Most Gracious (Allah) were recited to them, they fell down prostrating and weeping."

The tadabbur existence is checked through:

i. A person who is reading the Holy Quran should have unity in heart and mind.

ii. The dreadful and shuddering of feeling due to frightens of Allah Almighty.

iii. Faith of Allah Almighty should be developing.

iv. Improved in thoughtfulness of the heart while doing act of worship.

v. Adoration as a system of exhilaration of Allah Almighty.

\section{Tadabbur According to Scholars}

Shaykh Ibn Taymiyyah said: "The things demanded by the Qur'an are the understanding of its meanings, practicing with it, but if one does not take good care of himmah, he is not among the ones who are knowledgeable and pious." 10 
Al-Zarkashi said: "Anyone who does not have the knowledge, understanding, piety and tadabbur, he will not know anything about the deliciousness of the Qur'an."11

Ibn Qayyim said: "When one recites and tadabbur the Qur'an, and then he reaches to a verse that have an effect to his soul, therefore, repeat the verse even for a hundred of times even throughout the night, because reciting the verses of Allah in the state of appreciation, understanding and in-depth thinking are better than ending the recitation without tadabbur and understanding, which benefits the heart, whereby it enrich the intensity of faith and taste the sweetness in reading the Qur'an."12

\section{Tadabbur Methodologies (Qawa'id al-Tadabbur al-Amthal li Kitab Allah)}

The 40 methodologies under smaller groups of debated topics, which are:

1. Discuss on the Thematic of Chapter and Munasabat al-Quran.

2. Discuss on the Nuzul al-Quran.

3. Discuss on the technique of Arabic language and the structure of Quranic verses.

4. Discuss on Miracle of Balaghah al-Quran and Ilm'Bayani.

5. Discuss on Uslub al-Quran.

\section{Discussion on the Thematic of Chapter and Munasabat ul Quran}

- Method 1: Relation of Quranic verses with topic of content or relationship with other verses in a thematic way.

- Method 2: Unity with the theme of the content of holy book.

- Method 3: Understand the verse of the Holy Quran and its explanation.

- Method 5: Collect some parts of explanation of the Holy Quran to generalize overall meaning.

- Method 6: While doing interpretation there should be no repetition of verses.

- Method 7: Check the explanation of al MashhurTafseer.

- Method 8: Collect and combine the text with evidences.

- Method 17: Relation between texts of Holy book from its ending.

2. Discuss on the Nazul ul Quran

- Method 4: Interpretation of verses related to Nazul.

- Method 9: Findings of the stages of revelation of text of book. 
- Method 10: Categorization of Madinah and Makkah verses.

- Method 11: Observation on the source of Asbab ul Nazul.

3. Discussion on the Teaching of Arabic Language and the Structure of Quranic Verses

- Method 12: Understand the verses according to order of sentence structure.

- Method 13: There should be no contradiction with the Holy Quran and also with scientific facts.

- Method 15: Repetition of objectives and words.

- Method 16: Meaning of text of holy book should be understood.

- Method 18: Checking of the pronunciation.

- Method 19: There should two evidences of the Holy Quran.

- Method 25: Interpreting the text with arguments.

- Method 26: Check the techniques of Arabic.

- Method 27: There should be connection between the sentences for better understanding.

- Method 29: Reason behind each and every text of the Holy Quran should be discussed.

- Method 30: Using fil Mahdi in holy book. ${ }^{13}$

\section{Discussion on Miracles of the Holy Quran}

- Method 14: Describe words of the Holy Quran with its literal and technical meaning.

- Method 20: Describe qasam in holy book.

- Method 21: Discuss style of holy book.

- Method 22: Describe miracles of book of the Holy Quran.

- Method 24: Style of holy book to convey message of the Holy Quran.

- Method 28: Speech of the Holy Quran must be authentic and should be discussed.

- Method 31: Describe the khitab of Allah Almighty in interpretation.

\section{Discussion on Uslub al Qurani}

- Method 32: Every word of the Holy Quran should be discussed.

- Method 35: Addiatu fil in holy book.

- Method 37: Meaning of chapter. 
- Method 38: What is decided to exempt.

- Method 39: Pronounce word kazaalik.

- Method 40: Debate on ten Qiraat.

\section{The Importance of Tadabbur}

The main objective of the Holy Quran is to build humans as a righteousness person. Importance and profits of tadabbur al Quran are:

i. Tadabbur is the source of light. While listening to the Holy Quran the feelings comes in mind and heart. Allah Almighty said:

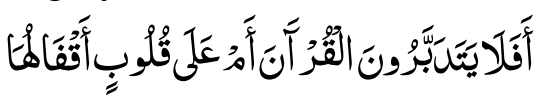

"Then do they not reflect upon the Qur'an, or are there locks upon [their] hearts?"14

ii. The act of listening and reading the Holy Quran and understanding the tadabbur because of this act Allah Almighty will grant love and protection.

iii. Tadabbur tells about the truth or mujiza of the Holy Quran. In the Holy Quran, Allah Almighty has discussed about stories of past states, about Day of Judgment, development of universe we came to know all about that by making tadabbur.

\section{The Method of Tadabbur Al-Quran}

The main methods of tadabbur are as follows:

\section{Understanding the Grammar of Arabic Language}

Information related to Arabic language and also of grammar, this will help to understand the meaning of text of the Holy Quran.

\section{Taqwa and Ikhlas}

The recitation of the Holy Quran is ibaadah and the Holy Quran is also said the light of Allah Almighty. Allah Almighty order humans to do acts of worship with honesty. Honesty will accept a sincere soul. The sincere soul has the capability of adapting and strengthening the commands of Allah Almighty.

\section{Capable of Appreciating the Beauty of Language}

A person who has the capability of appreciating the language beauty, this is the blessing from Allah Almighty. Because of this capability an Ijtihad occurs by 
the beauty of language. For example: While using the word (ya bunaiya) in Luqman's (may Allah bless him) story when he calls his son according to some scholar that phrase suggests reflect the love.

\section{Correlating with the Attribute of Asma al - Husna}

In the Holy Quran, Allah Almighty has described qualities, excellence and greatness. Because of this the reciter of the Holy Quran thinks that he is weak servant of Allah Almighty. Allah Almighty has described his attributes so that human remain fear from doing wrong things.

\section{Correlating with Sirah Nabawiyah}

The holy Quran explains the act and personality of prophet. Each and every act of prophet is a reflection of understanding of the text of the Holy Quran. For example, some companions came to Prophet Muhammad (peace be upon him) for asking about alcohol, the companions said give some opinion related to alcohol, Holy Prophet didn't answer of this, he gave explanation of this after the revelation of alcohol prohibition. ${ }^{15}$

\section{Supplementing Recital with certain Zikir and Du'a}

- Said by Holy Prophet, while reading (Your Justice, O Allah, for those who are content with you).

- When the Prophet Muhammad (peace be upon him) recited the end of Surah al-Mudathir, he said: My Lord has instructed: Be a pious man and do not create an associate for me as a God.

\section{Making the Quran a Cure and Prayer (Dua)}

The function of the Holy Quran is also comes as a cure and also as a dua. There are some suggestions in the Holy Quran that are used as cure and recited as dua.

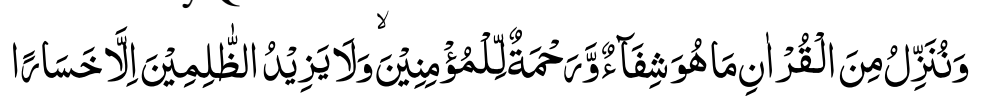

"And we send down of the Qur'an that which is healing and mercy for the believers."16

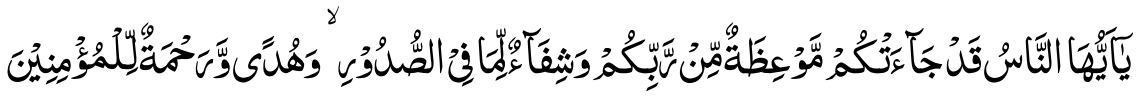

"Allah also said: "O mankind, there has to come to you instruction from your Lord and healing for what is in the breasts and guidance and mercy for the believers." 17 


\section{Reflecting the Quran with Sadness and Shedding Tears}

The Holy Prophet Muhammad (peace be upon him) cried whenever listen to the Holy Quran and then also he cries in prayer. Some companions read the Holy Quran in front of Prophet Muhammad (peace be upon him), he started crying while listening to the Holy Quran.

\section{Upholding Manners and Etiquette while Reciting the Holy Quran}

- Cleanliness is required for reading the Holy Quran. Cleanliness is needed for glorifying the words of Allah Almighty.

- Read the Holy Quran by starting Istia'azah, which is based on Quranic proposition.

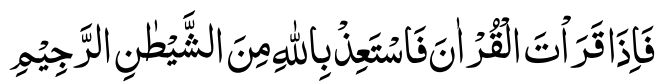

"So when you recite the Qur'an, (first) seek refuge in Allah from Satan, the expelled (from His mercy)." 18

- While reading of the Holy Quran, person who is reading the Holy Quran must read loudly and in clear voice and with tajwid or tartial.

\section{The Teaching and Learning of Tadabbur Al-Quran}

- Religiousness is focal part of defining the effectiveness of training of tadabbur on

a person who is reading the Holy Quran. Tadabbur made reflection and lights of guidance for each behavior and act of recite.

- Reading of the Holy Quran, person who is reading the Holy Quran must read loudly and in clear voice and with tajwid or tartial and the function of the Holy Quran is also as a cure and also as a dua.

- Appreciating the beauty of the language of the Holy Quran comparing with studies of scientific and from Seerah of prophet and with text of the Holy Quran.

\section{Practice of Tadabbur al-Quran}

It includes the following points:

i. While recitation of the Holy Quran there must be unity in heart and mind.

ii. Coming of the tears or shuddering the soul by the warning of Allah Almighty.

iii. Development of confidence and faith.

iv. While listening and reading verses of the Holy Quran one should be happy that such beautiful text has been revealed to them. 
v. Repeatedly say thanks to Allah Almighty.

vi. Frequently showing good behaviors.

\section{How to Make Tadabbur in 10 Steps}

These steps are as follows:

i. To love the Holy Quran

Everyone who read the Holy Quran first he/she should love the Holy Quran because that is a word of Allah Almighty. The tadabbur develops from heart and mind when you love the Holy Quran. While making tadabbur, first think why you love the Holy Quran.

ii. To be aware of the Purpose behind the Revelation of the Holy Quran

Every verse is revealed with some reason so humans must have information of why the text of the Holy Quran is revealed. This will help humans to understand the Holy Quran deeply.

iii. To make Tadabbur of what you have Memorized

It's easy to do tadabbur on verses which you know and not too easy on verses which you don't know.

iv. To make Tadabbur whilst you are Standing in Prayer

Ibn al-Qayyim says when someone starts his/her prayer Allah Almighty removes curtains between him and man and when you distract Allah Almighty make curtain again.

v. To Recite it during the Night

Tadabbur should be made at night because there will be peace in night and no one will distract you.

vi. To recite the Holy Quran Aloud and in a Melodious Manner

Recite the Holy Quran in loud voice, it will enter to your heart and mind also. That is useful for humans.

vii. To recite the Holy Quran with Tajwid without Rushing through it

If someone wants to make tadabbur in a good way then he should read verses slowly so that these verses absorb in your mind and heart.

viii. Repetition and Stopping in certain Places

One should read verses again and again so that it will absorb in your mind and will give benefit to humans.

ix. To split the Holy Quran and your Contemplation Sessions into Parts

Tadabbur should be made in parts. Because off this the text will be away from all mistakes and do whatever want to do but it should be according to Allah Almighty will. 
x. To make Connections between what you Experience and what Allah Almighty says in the Holy Quran

Whatever you experienced, make a connection between your experience and approach of the Holy Quran; this will make you to understand the Holy Quran in a better way.

\section{The Fruits that One will Gain from the Tadabbur}

These include the following:

i. From tadabbur one will get the knowledge of what is right and what is wrong. A person will keep away from wrong things because of tadabbur.

ii. Tadabbur provide happiness and moral strength to people.

iii. Allah Almighty made the Holy Quran as a bless book and whosoever read the Holy Quran and recite it will get blessings of Allah Almighty and Allah Almighty will protect hat man from every evil eye.

If a person read the Holy Quran and understand the meanings of it, it will help a person in every field of life. As it is said in the Holy Quran, "The believers are only those who, when Allah is mentioned, feel a fear in their hearts and when His Verses (this Quran) are recited unto them, they (i.e. the verses) increase their Faith; and they put their trust in their Lord (Alone)." ${ }_{19}$

A man who makes tadabbur in such a manner that has no contradiction with the Holy Quran, he will get a lot of blessings from Allah Almighty. As it is said, "Had it been from other than Allah, they would surely have found therein many contradictions." 20

Ibn al-Qayyim thinks over verse, "And it may be that you dislike a thing which is good for you and that you like a thing which is bad for you. Allah knows but you do not know."'21

\section{Conclusion}

The real research in the field is that which relates to the message of Islam as contained in the Holy Quran and Sunnah. Thinking is a basic tool of human's life. Thinking has different dimensions or shapes. The Holy Quran has used various terms for thinking such as tafakkur, tadhakkur, taddabbur, etc. Every term has its own meaning. If a person applies these terms in his everyday life it will give benefit to the people. Thinking is a blessing from Allah Almighty to humans. Tadabbur makes man righteousness person. The life in which people understand the Holy Quran and thinks about it deeply is a great blessing by 

Quranic Code of Tadabbur and its...

Allah Almighty, his/her life will become pleasant. Men who believe on words of the Holy Quran will get protection by Allah Almighty and Allah Almighty will help them in each and every field of life.

\section{References}

${ }^{1}$ Ishak Abdul Manaf, Ridzuan Ahmad, Ab. Halim Tamuri, and Khadijah Abdul Razak. "The Concept of Tadabbur and the Impacts of the 5 Minutes Program with Al-Quran: A Case Study among Student Teachers in IPG KSAH." Tinta Artikulasi Membina Ummah 3, no. 1 (2017), 100-114.

${ }^{2}$ Al Quran. Surah Nisa, verse 82

${ }^{3}$ Al Quran. Surah Sad, verse 29;

Jamal Badi. "Thinking' terminologies from Quronic perspective and their impact on human intellectual development." International Journal of Arab Culture, Management and Sustainable Development 2, no. 1 (2011), 41. doi:10.1504/ijacmsd.2011.044895.

${ }^{4}$ Musa'id bin Sulayman bin Nasir Tayyar. Mafhum al Tafsir wa al-ta'wil wa al-Istinbat, wa al-Tadabbur wa-al-Mufassir. Riyadh: Dar al-Jawzi, 2012. p.185.

${ }^{5}$ Abd Allah bin Dhaif Allah al-Rahili. Tadabbur al-Quran al-Karim. Vol.15. ed.1. (2010), 10-69

6 Yusuf Al-Qaradawi. Kaifa Nata 'amal ma'a al-Quran al-Azim. Ed.7. Kaherah: Dar al-Syuruq. 2009. p. 173- 175.

${ }^{7}$ Al Quran. Surah Anfal, verse 2

${ }^{8}$ Al Quran. Surah Taubah, verse 9

${ }^{9}$ Al Quran. Surah Maryam, verse 19

${ }^{10}$ Taqi uddin ibn Taymiyyah. al-Fatawa. juz.23. p.54.

${ }^{11}$ Al-Zarkashi. al-Burhan fi 'Ulum al-Quran, jil. 2. p.171.

${ }^{12}$ Salman bin Umar al-Sunaidi. (2002). Tadabbur al-Quran. Riyadh: al-Bayan.

13 Nurul Zakirah Mat Sin. "The Definition of Qawa'id Al-Tadabbur: A Comparison Analysis with Qawa'id Al-Tafsir." International Journal of Quranic Research 6, no. 1 (2014), 63-82. doi:10.22452/quranica.vol6no1.5.

${ }^{14}$ Al Quran. Surah Muhammad, verse 24

${ }^{15}$ Al Quran. Surah Maidah, verse 90

${ }^{16} \mathrm{Al}$ Quran. Surah Isra, verse 82

${ }^{17}$ Al Quran. Surah Yunus, verse 57

${ }^{18}$ Al Quran. Surah Nahl, verse 98 
${ }^{19}$ Al Quran. Surah Anfal, verse 2

${ }^{20} \mathrm{Al}$ Quran. Surah Mominun, verse 68

${ }^{21}$ Al Quran. Surah Baqarah verse 216 